\title{
Jan Falkowski
}

Uniwersytet Kazimierza Wielkiego, Instytut Geografii

\section{Tradycyjne i innowacyjne kierunki polskich badań geograficzno-rolniczych oraz ich miejsce $w$ geografii}

\begin{abstract}
Zarys treści: Celem artykułu jest podjęcie dyskusji na temat miejsca geografii rolnictwa w polskim systemie nauk geograficznych. Wyróżniono 5 zasadniczych okresów badawczych (od lat 30. ub. wieku do 2013 r.) w 12 geograficznych ośrodkach naukowych. Wśród tradycyjnych 15 kierunków badań wymieniono m.in.: użytkowanie ziemi, typologię i regionalizację rolnictwa, organizację i strukturę przestrzenną rolnictwa, rolnictwo podmiejskie, rolnicze obszary problemowe, rolnictwo ekologiczne, rolnictwo w planowaniu przestrzennym, rolnictwo Polski i świata. Wyróżniono też 13 kierunków innowacyjnych w badaniach geografii rolnictwa i obszarów wiejskich, np.: nowe metody i techniki badawcze, kształtowanie krajobrazu multisensorycznego, możliwości rozwoju ekoenergetyki, formy i metody poprawy jakości życia i wzrostu kapitału ludzkiego i społecznego, wykorzystanie ICT (technik informacyjno-telekomunikacyjnych), alternatywne źródła dochodów gospodarstw, geografię klastrów innowacji, nową organizację badań geograficznych. Ważnym problemem jest dalsza droga rozwoju badań geograficzno-rolniczych w geografii obszarów wiejskich, która nie powinna utracić niczego $z$ dotychczasowego dorobku, a jednocześnie stać się ważną częścią geografii społeczno-ekonomicznej i szerzej nauk geograficznych.
\end{abstract}

Słowa kluczowe: ośrodki geografii rolnictwa, kierunki badań: tradycyjne i innowacyjne, strategia rozwoju

\section{Miejsce geografii rolnictwa w polskiej geografii - etapy rozwoju i ośrodki badawcze}

Wiek XX przyniósł $\mathrm{w}$ badaniach naukowych istotne zmiany poprzez dążenie do coraz większej specjalizacji i szczegółowości. To dzięki temu udało się dokonać wielu odkryć nie tylko w sensie globalnym. Również nauki geograficzne poszły w kierunku poznawania rzeczywistości przez prowadzenie badań specjalizacyjnych $\mathrm{w}$ obrębie poszczególnych subdyscyplin. Wydaje się, że uzyskując nowe wartości, metody i wyniki dzięki pogłębionej analizie zjawisk i procesów, część 
prac badawczych, zwłaszcza o drugorzędnym charakterze, doprowadziła do zbędnego rozproszenia i powierzchownego potraktowania problematyki geograficznej (w tym także geograficzno-rolniczej).

$\mathrm{Na}$ obecnym etapie geografia rolnictwa zajmuje się badaniem:

- związków produkcji rolniczej z elementami środowiska geograficznego (przyrodniczego);

- relacji rolniczego wykorzystania ziemi w strukturze całościowego użytkowania ziemi (gruntów);

- zjawisk i procesów społeczno-własnościowych w rolnictwie w strukturze czynników demograficzno-społecznych;

- zjawisk i procesów organizacyjno-technicznych w rolnictwie w strukturze organizacji i zarządzania;

- zjawisk i procesów produkcyjnych $\mathrm{w}$ rolnictwie $\mathrm{w}$ produkcji globalnej i towarowej;

- konsekwencji przyrodniczych, społecznych i ekonomicznych w rolnictwie pod wpływem kapitału krajowego i zagranicznego (środków unijnych) oraz w wyniku celowej strategii rozwoju (polityki państwa, planowania przestrzennego i strategicznego);

- zróżnicowania przestrzennego rolnictwa (typów i regionów rolniczych) w strukturze regionalnej, krajowej, Unii Europejskiej i światowej.

W 2008 r. przedstawiono propozycję wyodrębnienia pięciu okresów badań geograficzno-rolniczych w Polsce (Falkowski 2008, s. 144-145), wyróżniając:

I. Okres międzywojenny (głównie lata 30. ub. wieku), w którym geografowie i ekonomiści rolni zajmowali się analizami geograficzno-rolniczymi w szerszych monografiach, ujęciach metodycznych oraz typologiczno-regionalizacyjnych rolnictwa Polski (prace: F. Bujaka, F. Dziedzica, J. Ernsta, J. Lotha, W. Ormickiego, A. Sujkowskiego, S. Srokowskiego, A. Żabko-Potopowicza).

II. Okres powojenny (1945-1960), zaznaczony wykorzystaniem w polskiej geografii rolnictwa zagranicznych wzorców teoretyczno-metodycznych (głównie brytyjskich, francuskich i niemieckich). Efektem były mapy użytkowania ziemi, monografie regionalne, różne rozwiązania metodyczne (prace: J. Dylika, J. Fiericha, J. Kostrowickiego, T.M. Milewskiego, S. Srokowskiego, J. Szaflarskiego, J. Tobjasza, F. Uchorczaka).

III. Okres lat 60. XX w. (1961-1969), obejmujący przede wszystkim opracowanie koncepcji sporządzania przeglądowych i szczegółowych map użytkowania ziemi przez Zakład Geografii Rolnictwa IGiPZ PAN w Warszawie pod kier. prof. J. Kostrowickiego (wykonanie map np. dla województwa białostockiego, powiatów: bielsko-podlaskiego, mrągowskiego), dla m. Krakowa i powiatu krakowskiego mapy użytkowania ziemi wykonał zespół pod kier. prof. K. Bromka. $\mathrm{W}$ tym okresie powstały też prace dotyczące stref żywicielskich kilku większych miast Polski.

IV. Okres lat 70. i 80. XX w. (1970-1989), będący kontynuacją ujęć typologiczno-regionalizacyjnych rolnictwa Polski, Europy i świata (opracowano m.in.: mapę typów rolnictwa Europy - J. Kostrowicki z zespołem, typologię rolnictwa Polski - R. Szczęsny z zespołem). W tym czasie coraz powszechniej sto- 
sowano w wielu geograficznych ośrodkach uniwersyteckich metody ilościowe (matematyczno-statystyczne), zwłaszcza w IGiPZ PAN w Warszawie i UAM w Poznaniu. W 1973 r. ukazał się pierwszy akademicki podręcznik do geografii rolnictwa świata prof. J. Kostrowickiego - „Zarys geografii rolnictwa”. W latach 80 . ub. wieku powstały kolejne podręczniki geografii rolnictwa Polski, m.in.: W. Stoli i R. Szczęsnego (1982 r., ale pierwszy w 1976 r.) oraz T. Olszewskiego (1985 r.). Od 1984 r. organizowane są przez Komisję Geografii Rolnictwa i Gospodarki Żywnościowej (od 2001 r. działającą jako Komisja Obszarów Wiejskich) Polskiego Towarzystwa Geograficznego każdego roku seminaria geograficzno-rolnicze (geografii wsi) oraz wydawane publikacje konferencyjne.

V. Przełom wieku XX i XXI (okres transformacji), który można umownie podzielić na dwa podokresy: pierwszy obejmujący lata 1990-2003 - początków transformacji ustrojowej (przedakcesyjny) i drugi od 2004 r. do chwili obecnej (okres zaawansowanej transformacji, tj. od członkostwa Polski w UE, zwany też akcesyjnym). W latach 1990-2003 powstało wiele prac obejmujących przekształcenia funkcjonalno-strukturalne i przestrzenne rolnictwa jako konsekwencję zmian ustrojowych w Polsce (Jasiulewicz 1998, Rydz 1998, Bański 2001, Falkowski 2001, XVII-XIX Seminarium Geograficzno-Rolnicze, w latach 2001-2003). Dużym walorem opracowań geograficzno-rolniczych tego podokresu jest uzyskanie wiedzy na temat pozytywnych i negatywnych konsekwencji transformacyjnych w rolnictwie (IX-XII, XVII-XIX Seminarium Geograficzno-Rolnicze, w latach 1992-1995, 2001-2003). Ujemną stroną badań - moim zdaniem - było nadmierne rozproszenie problematyki, skromna liczba całościowych syntez i określenia roli oraz miejsca rolnictwa polskiego w strukturze krajów Unii Europejskiej. Wydaje się, że sytuacja ta trwa również w drugim podokresie (w latach 2004-2013). W tym czasie powstało wiele opracowań, które kontynuowały problematykę wpływu restrukturyzacji na rolnictwo polskie oraz wykorzystania funduszy UE dla modernizacji rolnictwa polskiego (Rydz 2006, Bański 2007, Rudnicki 2010, Rudnicki 2010a). Nastąpiło też wyraźne powiązanie problemów geograficzno-rolniczych z problematyką obszarów wiejskich, które ze swej natury są wielofunkcyjne i obejmują też liczne zagadnienia pozarolnicze (Bański 2004, 2013, Falkowski 2004, Komornicki, Kulikowski 2009, Rydz, Rudnicki 2009, Kurowska, Gwiaździńska-Goraj 2012). Wyrażam jednak pogląd, że póki rolnictwo zajmuje wysoką pozycję w strukturze rolniczego użytkowania ziemi, zatrudnieniu, usługach, infrastrukturze technicznej, powiązaniach z turystyką i rekreacją oraz innymi działami gospodarki (por. Głębocki 2005, 2013), geograficzno-rolnicze problemy badawcze będą wciąż odgrywały kluczową rolę na obszarach wiejskich Polski.

Od lat 70. ub. wieku do dziś ukształtowało się w Polsce kilka ośrodków geografii rolnictwa (i geografii wsi). Czapiewski i Kulikowski (2005), przedstawiając dorobek naukowy geografii rolnictwa wymieniają 7 ośrodków uniwersyteckich, 3 - akademii pedagogicznych, 1 - politechniki i 1 - Polskiej Akademii Nauk. Zakład Geografii Rolnictwa IGiPZ PAN w Warszawie (później Zespół Badań Obszarów 
Wiejskich, a obecnie Zakład Geografii Wsi i Rozwoju Lokalnego) opublikował 246 prac w latach 1957-2004, w tym m.in.: J. Bańskiego, W. Biegajły, B. Gałczyńskiej, W. Jankowskiego, J. Kostrowickiego, R. Kulikowskiego, A. Stasiaka, W. Stoli, R. Szczęsnego, J. Szyrmera, W. Tyszkiewicz i W. Zglińskiego). Wybrane pozycje bibliograficzne z geografii rolnictwa Wydziału Geografii i Studiów Regionalnych Uniwersytetu Warszawskiego obejmują 82 opracowania głównie: A. Dembicza, E. Dramowicz, M. Durydiwki, J. Gudowskiego, M. Jędrusika, E. Kantowicz, J. Makowskiego, S. Osińskiego, F. Plita, M. Skoczka, M. Skotnickiego, J. Tobjasza i J. Winidowej. W Instytucie Geografii UMK w Toruniu wykazano 225 publikacji, w tym: M. Biczkowskiego, J. Falkowskiego, A. Jezierskiej-Thole, M. Kluby, L. Kozłowskiego, R. Rudnickiego. Ośrodek krakowski (UJ i AP) zamieścił 225 wybranych pozycji bibliograficznych, w tym: K. Bromka, M. Dobrowolskiej, Z. Górki, B. Górza, C. Guzika, W. Kurka, M. Nowakowskiego, W. Ormickiego (1927-1937), A. Prochownik, L. Sawickiego (1911-1919) i R. Uliszaka. Poznański ośrodek uniwersytecki przedstawił 52 syntetyczne (głównie monograficzne) opracowania, w tym: B. Głębockiego, E. Jędryczki (Kasprzak), U. i T. Kaczmarek, A. Kołodziejczak i M. Polnej. W Instytucie Nauk o Ziemi UMCS w Lublinie zamieszczono 124 pozycje bibliograficzne, w tym: J. Antoszek, J. Ernsta, R. Jeduta, W. Sobczyk, H. Swić i F. Uhorczaka (1951-1963). Wydział Nauk o Ziemi UŚ w Sosnowcu podał 134 wybrane publikacje, w tym: E. Dusia, Z.J. Kamińskiego, L. Langhamera, A.Z. Szajnowskiej, J. Tkocza i A. Wrony. Wybór dorobku geograficzno-rolniczego ośrodka słupsko-koszalińskiego (PAP w Słupsku i PK w Koszalinie) obejmuje 101 pozycji bibliograficznych, w tym: L. Brożka, G. Czapiewskiej, U. Gołębiewskiej, M. Jasiulewicza, S. Łacha, S. Miklosa, E. Rydza, S. Szały. Instytut Geografii Akademii Świętokrzyskiej w Kielcach przedstawił 153 opracowania, w tym: R. Burka, M. Kozieja, J. Mityka, E. Pałki, M. Strzyż, M. Śmigielskiej i J. Wrońskiej. Instytut Geografii i Rozwoju Regionalnego Uniwersytetu Wrocławskiego podaje 65 wybranych opracowań, w tym: S. Golachowskiego, S. Grykienia, W. Hasińskiego, A. Jagielskiego, J. Januszewskiego i J. Łobody.

W przedstawionych powyżej ośrodkach wybrane pozycje bibliograficzne z geografii rolnictwa (i obszarów wiejskich), głównie z lat 1950-2004, obejmują łącznie około 1400 publikacji. Pełny wykaz publikacji z geografii rolnictwa z lat 1918-1998 (z wyjątkiem 1928-1935) obejmuje 2579 pozycji, z geografii przemysłu 2543 i z geografii komunikacji 2417 (Taylor 2008). Dużym osiągnięciem organizacyjno-naukowym jest fakt, że we wspomnianych wyżej ośrodkach naukowych przeprowadzono kilkanaście habilitacji i obroniono kilkadziesiąt doktoratów z geografii rolnictwa i obszarów wiejskich.

Dorobek naukowy polskiej geografii rolnictwa byłby niepełny, gdyby nie uwzględnić osiągnięć prac Komisji Geografii Rolnictwa i Gospodarki Żywnościowej PTG, powstałej w 1984 r., a od 2001 r. działającej pod nazwą Komisji Obszarów Wiejskich PTG (Bański 2005). Celem interdyscyplinarnych spotkań seminaryjnych jest prezentacja aktualnych problemów geografii rolnictwa (i obszarów wiejskich), mających silny związek z bieżącymi przemianami ustrojowymi w Polsce oraz potrzebami planowania przestrzennego (Falkowski 1993). W 2013 r. odbyło się XXIX Ogólnopolskie Seminarium Geograficzno-Rolnicze 
w Łodzi poświęcone wielofunkcyjnym obszarom wiejskim (Wójcik 2013). Prawie wszystkie seminaria kończyły się publikacjami materiałów pokonferencyjnych. Od 2000 r. ich rolę przejęła seria wydawnicza - Studia Obszarów Wiejskich (Rural Studies). W 2013 r. ukazał się XXXI t. ww. serii. Ośrodki organizujące seminaria $\mathrm{w}$ miarę swoich możliwości wydają dodatkowe publikacje, zawierające zgłoszone referaty. Dzieje się tak np. w Słupsku, Krakowie, Kielcach, a ostatnio także w Łodzi.

\section{Tradycyjne i innowacyjne kierunki badań}

Przedstawione wyżej ośrodki geografii rolnictwa koncentrują się na kilkunastu problemach badawczych o charakterze teoretycznym, metodycznym i aplikacyjnym. W diagnozie stanu i perspektyw rozwoju geografii w Polsce, opracowanej w 2008 r. (Liszewski i in. 2008), w zakresie geografii rolnictwa wymienia się 15 następujących kierunków: (1) użytkowanie ziemi; (2) typologia i regionalizacja rolnictwa; (3) struktura i organizacja przestrzenna rolnictwa; (4) uwarunkowania przyrodnicze rolnictwa; (5) struktura agrarna; (6) rolnictwo podmiejskie - strefa żywicielska; (7) czynniki kształtujące strukturę produkcji rolniczej; (8) obszary problemowe rolnictwa; (9) rolnictwo ekologiczne; (10) gospodarka żywnościowa; (11) produkcja rolnicza; (12) rolnictwo w planowaniu przestrzennym; (13) rolnictwo Polski i wybranych państw świata; (14) krajobrazy rolnicze/wiejskie; (15) przemiany społeczno-ekonomiczne i przestrzenne obszarów wiejskich (Falkowski i in. 1992, Głębocki 1998, Jasiulewicz 1998, Falkowski 2008). Wyżej wymienione kierunki można w pewnym sensie nazwać tradycyjnymi, gdyż reprezentują podstawową problematykę badawczą w polskiej geografii rolnictwa w całym analizowanym okresie (1932-2004). Nie wydaje się, aby w najbliższych latach problematyka ta nie była kontynuowana, co najwyżej ulec może zmianom rozłożenie jej akcentów w celu przystosowania kierunków badań do wymagań wspierania działalności innowacyjnej w badaniach geograficznych i ograniczenie ilościowe (prac o charakterze lokalnym, cząstkowym) na rzecz opracowań o charakterze innowacyjnym, kompleksowym, syntez teoretyczno-metodycznych i aplikacyjnych, umożliwiających aktywniejsze niż dotąd włączenie się polskiej geografii rolnictwa w nurt badań międzynarodowych.

Do tradycyjnych (ale jednocześnie w nowym ujęciu) kierunków badań w najbliższych latach zaliczyłbym te, które pogłębiają zarówno teorię, jak i metodologię geografii rolnictwa, a jednocześnie porządkują i kontynuują problematykę w systemie nauk geograficznych, zwłaszcza: (1) współczesne czynniki determinujące zmienność, kierunki i poziom rozwoju przestrzennego rolnictwa (np. konfliktowe, lokalizacyjne, rynkowe); (2) wielofunkcjonalne modele konceptualne rolnictwa na bazie badań w skali lokalnej, regionalnej i krajowej; (3) nowe koncepcje teoretyczno-aplikacyjne jako wynik poszukiwania nowych narzędzi opisu i wyjaśniana zjawisk geograficzno-rolniczych (i pozostałych na obszarach wiejskich); (4) analizy przestrzenne, czyli badanie układów, powiązań sieciowych i struktur przestrzennych w środowisku przyrodniczym dla rolnictwa, użytkowania ziemi, 
rozmieszczenia produkcji, gęstości kapitału ludzkiego itp.; (5) oceny jakościowe przekształceń transformacyjnych rolnictwa polskiego (w strukturze agrarnej, zasobach pracy, czynnikach intensyfikacji, zasobach gruntów - w dobrej lub złej kulturze rolnej - produkcji roślinnej i zwierzęcej, produkcji globalnej i towarowej); (6) wykorzystanie wyników badań geografii rolnictwa w strategii rozwoju regionalnego Polski; (7) studia porównawcze rolnictwa polskiego z krajami UE i innych regionów świata. Kierunki powyższe należą do klasycznych programów badawczych i są wyrazem ewolucyjnej drogi w badaniach geograficzno-rolniczych.

Drugi nurt badań, zwany innowacyjnym, stanowi poszukiwanie nowych metod, wartości, problemów. O ile prekursor teorii innowacji Schumpeter (1960) uważał, że innowacja jest wprowadzeniem do praktyki nowego rozwiązania, głównie o charakterze technicznym, oddziałującego na gospodarkę, to współcześnie panuje pogląd, że innowacje są nie tylko „produktowe, procesowe, marketingowe, organizacyjne", ale są nimi też nowe idee, koncepcje teoretyczne itp., które rozpowszechniają się $\mathrm{w}$ przestrzeni geograficznej i strukturach organizacyjnych (Kukliński, Pawłowska 1998, Guzik 2004, Kukliński 2005, Parteka, Kasprzak 2008). Innowacyjność to po prostu każda zmiana, która coś ulepsza, daje nowe jakości lub pozwala stworzyć nowy produkt czy usługę (Świadek 2008). Silva Rodriguez uważa, że... „innowacyjność jest pojęciem, które można powiązać z każdą dziedziną działalności na wsi”, natomiast Gregory dodaje, że „innowacyjne pomysły są wynikiem dyskusji między ludźmi, którzy mają dużą wiedzę na dany temat, ale bardzo odmienne doświadczenia i perspektywy zawodowe" (Wspólnoty Europejskie 2009, s. 32, 53). Zatem innowacyjność, gdy przynosi nowe wartości w dotychczasowej wiedzy, w teorii, ujęciu metodologicznym i wdrożeniowym, można by określić mianem rewolucyjnego mechanizmu rozwoju nauki lub co najmniej nowego paradygmatu trwałego rozwoju (por. Chojnicki 2000, Kukliński 2005, Rainko 2011, Maik 2012). Według metodologii OECD nakłady na działalność innowacyjną obejmują wydatki na: działalność badawczo-rozwojową, zakup gotowej technologii, środki trwałe konieczne do wdrożenia innowacji (w tym: maszyny, urządzenia techniczne, budynki, budowle, grunty), szkolenia, marketing oraz prace wdrożeniowe (Li, Kozhikode 2009). Innowacje polegają na reorientacji gospodarki opartej na pracy w gospodarkę będącą efektem wykorzystania wiedzy i zacieśnienia powiązań pomiędzy elementami systemu innowacji, a więc między nauką, techniką, edukacją, przedsiębiorstwami, rynkiem, administracją (rządową i samorządową), organizacjami pozarządowymi itp. W szerszym wymiarze kreatywnością i innowacyjnością obszarów wiejskich zajmuje się Europejska Sieć na rzecz Rozwoju Obszarów Wiejskich Unii Europejskiej (Wspólnoty Europejskie 2009).

O wdrażaniu innowacyjności w rolnictwie (na obszarach wiejskich) decydują też samorządowe władze lokalne i regionalne, instytucje otoczenia biznesu, ośrodki postępu naukowego i technologicznego. Rolnictwo jest także działem biznesowym, a innowacyjność dotyczy zarówno nowoczesnych rozwiązań technologicznych, technicznych, jak i menedżerskich i organizacyjnych oraz zasobów o charakterze materialnym, a tym bardziej niematerialnym. Jak słusznie zauważają Tamowicz i Szultka (2005, s. 127), „rola innowacji we współczesnej gospodarce 
uzasadnia określenie jej mianem wiedzochłonnej, w odróżnieniu od poprzedniego modelu gospodarki pochłaniającego zasoby". Innowacyjność to połączenie lokalnych tradycji i dotychczasowych metod działania $z$ wiedzą dostosowaną do nowoczesnego konsumenta i rynku.

Efektem innowacji są klastry, czyli geograficzne skupiska wyspecjalizowanych, konkurujących ze sobą i współpracujących przedsiębiorstw oraz instytucji otoczenia (np. uczelnie, szkoły, stowarzyszenia branżowe), z którymi wchodzą one w silne interakcje. Klastry powstają niemal we wszystkich sektorach gospodarki, zwłaszcza w przemyśle, usługach, rolnictwie (Wolak-Sikorska 1993, Wojnicka i in. 2001, Wojnicka 2002, Szymoniuk 2005, Ciok, Dobrowolska-Kaniewska 2009). W rolnictwie mogą to być np.: przedsiębiorstwa sadownicze, ogrodnicze, hodowli trzody chlewnej, drobiu, przemysłu spożywczego itp), platformy technologiczne służące przygotowaniu programów badawczo-rozwojowych, integracji kluczowych partnerów gospodarczych i badawczych, mobilizacji środków finansowych itp. (np. w województwie pomorskim wśród 22 platform technologicznych są takie, jak: platforma technologiczna żywności, środowiska, procesów produkcji) oraz systemy innowacyjne o wymiarze geograficznym, czyli np. Grójecko-Warecki Rejon Sadowniczy, Żuławski Region Hodowlany, Bursztynowy Szlak Dziedzictwa Kulturowego na Podkarpaciu, Nowosądecki Rejon Sadowniczy, podmiejskie strefy żywicielskie itp. Ważnym elementem innowacyjności w badaniach jest konieczność zastosowania wyników w praktyce (aplikacja, charakter utylitarny). Nie mniej istotnym aspektem innowacji jest jej rozprzestrzenianie się (dyfuzja innowacji) do innych regionów, krajów, na inne kontynenty. Duże znaczenie ma również zdolność adaptacyjna innowacji we wszystkich trzech wymiarach (teoretycznym, metodycznym i aplikacyjnym). Tradycyjne czynniki produkcji: ziemia, praca i kapitał, wciąż istotne dla rozwoju gospodarczego, coraz silniej są związane $z$ wiedzą, która staje się źródłem bogactwa i najważniejszym czynnikiem produkcji. Innowacje oparte na wiedzy sprzyjają tworzeniu nowych form aktywności produkcyjnej, usługowej i organizacyjnej, a nawet są warunkiem przetrwania (Ciok, Dobrowolska-Kamieńska 2009). W procesie innowacji rolnictwa i obszarów wiejskich mogą wystąpić też bariery, takie jak: rozdrobniona struktura agrarna, niski poziom wiedzy rolniczej i ogólnej, niewystarczające ilości środków produkcyjnych, zwłaszcza nowoczesnych, brak jasnej sytuacji co do przyszłości gospodarstw domowych itp. (Wójcicki 2000, 2011).

Wśród szczegółowych propozycji problemowych, które są, moim zdaniem, próbą włączenia się geografii rolnictwa (i szerzej obszarów wiejskich) w nurt badań innowacyjnych i zarazem wypracowania aktualnych i ważkich celów badawczych, można wymienić następujące kierunki i zadania, z których część jest już realizowana co najmniej od $2004 \mathrm{r}$.:

1. Rozszerzenie pola badawczego geografii rolnictwa m.in. przez powiązanie teoretyczno-metodyczne z innymi branżami, strukturami, sieciami, występującymi na obszarach wiejskich, z wykorzystaniem nowych narzędzi i metod badawczych (np. teledetekcji, informatyzacji, GIS-u, Internetu itp.), ujęć jakościowych w miejsce dominacji ujęć ilościowych i rozproszenia problematyki badawczej, które z trudem poddają się systematyzacji, rozpoznanie mechani- 
zmów w zespołach interdyscyplinarnych celem określenia mocnych i słabych stron geografii rolnictwa i obszarów wiejskich. Istnieje pilna potrzeba realizacji dużych programów badawczych (interdyscyplinarnych, interregionalnych), kończących się określonymi syntezami.

2. Konstruowanie nowych modeli analityczno-opisowych, wzorców kompleksowych, syntetycznych i systemowych rolnictwa (i innych działów gospodarki obszarów wiejskich), w warstwie teoretycznej, metodologicznej i empirycznej, jako wynik wpływu transformacji, integracji, innowacji, globalizacji, np.: nowoczesne kartowanie użytkowania ziemi, nowe ujęcie typologii i regionalizacji (rolnictwa i obszarów wiejskich), sugestie do urzędów statystycznych o organizowanie i dostarczanie wiarygodnych materiałów źródłowych zarówno w sensie ilościowym, jak i jakościowym.

3. Metody i formy optymalnego kształtowania krajobrazu/regionu multisensorycznego (rolniczego, wiejskiego), w warunkach ekologizacji środowiska (czyli zwiększenia różnorodności biologicznej, „zielonego otoczenia”, ekstensywnych form produkcji rolnej, ochrony bioklimatu, czystości wód i najlepszych gleb, rozwiązywania konfliktów funkcjonalno-przestrzennych) i nowoczesnego planowania oraz zarządzania przestrzenią.

4. Badanie możliwości wykorzystania ekoenergetyki (bioenergetyki) na obszarach wiejskich i w rolnictwie $\mathrm{w}$ postaci energii $\mathrm{z}$ biomasy (np. upraw zbożowych, rzepaku, ziemniaków, miskantu olbrzymiego, wierzby i topoli) oraz pozyskiwania energii ze źródeł odnawialnych, np. słonecznej, wiatrowej, wodnej, geotermalnej itp., m.in. przez zwiększenie nakładów na OZE (odnawialne źródła energii).

5. Badanie poprawy jakości życia, a także zdolności wzrostu intelektualnego kapitału ludzkiego i społecznego (szkolenia, warsztaty, coaching, telepraca, upowszechnienie dostępu do łączności szerokopasmowej i wykorzystanie ICT) oraz mobilności zawodowej w rolnictwie (wskaźniki: młodości demograficznej, wieku produkcyjnego i poprodukcyjnego), badanie pozostałych procesów społeczno-demograficznych, np. procesu starzenia się społeczności wiejskiej (zwłaszcza rolniczej), zahamowanie nadmiernego odpływu migracyjnego (zmniejszenie stopy bezrobocia) oraz możliwości wykorzystania innowacji w sferze opieki medycznej i innych form zabezpieczenia społecznego ludności wiejskiej.

6. Ocena zdolności wykorzystania kapitału lokalnego (własnego, samorządowego), regionalnego i krajowego oraz obcego (np. UE) w rolnictwie, biotechnologii, energetyce, infrastrukturze, usługach i przetwórstwie oraz ochronie i kształtowaniu środowiska.

7. Wpływ działań innowacyjnych na wielość, elastyczność i zmienność specjalizacji produkcyjnych i przetwórczych $\mathrm{w}$ rolnictwie oraz pozostałych działach gospodarki na obszarach wiejskich.

8. Ogólnohumanistyczne i marketingowe wykorzystanie wartości kulturowych środowiska rolniczego (obszarów wiejskich), a więc historii, sztuki, tradycji, dziedzictwa kulturowego wsi, zróżnicowanych krajobrazów wiejskich itp.

9. Zróżnicowanie regionalne poziomu wykorzystania technik informacyjno-telekomunikacyjnych (pełny dostęp do ICT) w rolnictwie (elektroniczna księgo- 
wość, edukacja, bankowość, marketing itp.) oraz innych działach gospodarki na obszarach wiejskich w sferze usług produkcyjnych i handlowych (np. w handlu elektronicznym, logistyce zaopatrzenia i zbytu itp.).

10.Alternatywne źródła dochodów gospodarstw na obszarach wiejskich, np. zagospodarowanie pozarolnicze ziemi, usługi informatyczne, logistyczne, doradcze (np. prawno-finansowe), handlowe i pozostałe usługi produkcyjne i nieprodukcyjne (np.: administracja, edukacja, ochrona zdrowia i opieka socjalna, hotelarstwo, gastronomia, transport, obsługa nieruchomości), budownictwo, mieszkalnictwo, gospodarka komunalna, przemysł, wytwarzanie energii, przetwórstwo, rzemiosło, agroturystyka, rekreacja, leśnictwo, łowiectwo, rybactwo i rybołówstwo śródlądowe, ochrona środowiska, kształtowanie krajobrazu itp.

11.Współczesne i perspektywiczne konsekwencje innowacji w rolnictwie i na obszarach wiejskich (problemy, progi, bariery) - ocena w wymiarze europejskim, krajowym i regionalnym, pozwalająca na jeszcze aktywniejsze włączenie się geografów rolnictwa i obszarów wiejskich do geografii światowej i zrealizowanie wielu programów międzynarodowych.

12. Geografia klastrów innowacyjności w systemie struktury przestrzennej rolnictwa (obszarów wiejskich) jako wynik innowacji w trzech płaszczyznach: teoretycznej, metodycznej i aplikacyjnej, warunkująca atrakcyjność lokalizacyjną danego obszaru (regionu), także dla potencjalnych inwestorów krajowych i zagranicznych.

13. Nowa organizacja badań naukowych, integrujących najpierw subdyscypliny (np. połączenie geografii rolnictwa i geografii obszarów wiejskich), następnie kilka ośrodków naukowych w celu zrealizowania ważnych projektów lub programów naukowo-badawczych wraz z coraz silniejszym włączeniem się w nurt badań krajów UE i Europy Środkowo-Wschodniej i jeszcze szerzej geografii międzynarodowej.

Strategia innowacji w rolnictwie danego regionu (kraju) wymaga określonego wsparcia finansowego $z$ funduszy lokalnych, regionalnych i budżetu państwa, ale także ze środków UE, w tym: w ramach Europejskiego Funduszu Rozwoju Regionalnego (EFRR), Funduszu Spójności (FS) oraz Europejskiego Funduszu Społecznego (EFS). Powoduje to, że dany region rozwija się w znacznym stopniu dzięki integracji z Unią Europejską. Istnieją też liczne organizacje międzynarodowe, które wspierają badania innowacyjne $\mathrm{w}$ rolnictwie i dla obszarów wiejskich, takie jak np.: Organizacja ds. Wyżywienia i Rolnictwa ONZ, Bank Światowy, Amerykański Bank Rozwoju, Stały Komitet ds. Badań Naukowych w Dziedzinie Rolnictwa (SCAR) itp. W efekcie jest szansa, że rolnictwo jako jeden z najważniejszych działów gospodarki Polski może skutecznie poprawić poziom wskaźnika innowacyjności Polski (European Commission Innovation... 2006, European Innovation Scoreboard 2008), zarówno w skali Unii Europejskiej (w 2008 r. 5 miejsce od końca wśród 27 państw UE - por. ryc. 1), jaki w stosunku do grupy 8 najbardziej wpływowych państw świata (G8).

Dziś takie czynniki, jak: niska produktywność, niski poziom zatrudnienia, małe wydatki na badania i rozwój, skutecznie zaniżają wspomniany wskaźnik innowacyjności. Dlatego niezbędne jest poszukiwanie nowych lub adaptowanie 


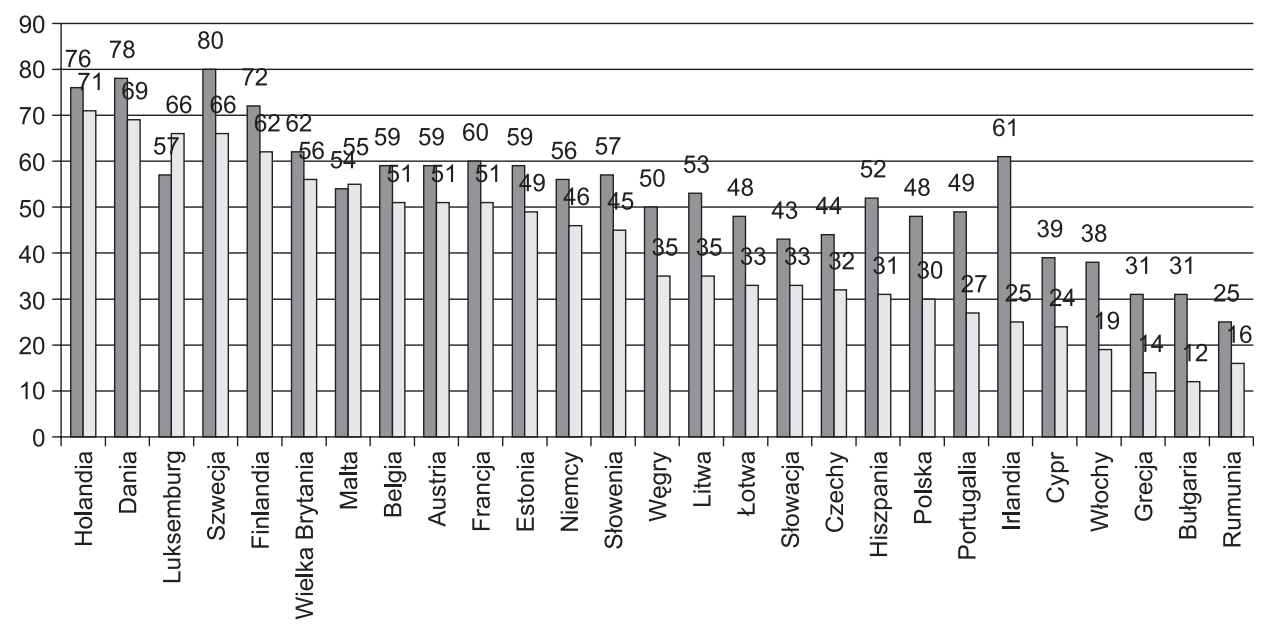

$\square$ Miasto $\square$ Wieś

Ryc. 1. Poziom wskaźnika innowacyjności w 27 państwach Unii Europejskiej (2008) Źródło: Wspólnoty Europejskie (2009, s. 53).

istniejących dobrych wzorców współpracy pomiędzy różnego typu podmiotami działającymi w poszczególnych regionach kraju i poza jego granicami. Wszystkie regiony (zwłaszcza rolnicze, które dominują w strukturze przestrzennej kraju) stają zatem w obliczu konieczności restrukturyzacji, modernizacji i wspierania ciągłych innowacji w różnych sferach gospodarki rolnej (Pietrzyk 2004, Błasiak 2005, Bąkowski i in. 2007, Churski 2008). Wydaje się, że w polskiej rzeczywistości przestrzennej obszarów wiejskich co najmniej do 2030 r. obok tzw. wsi tradycyjnych rozwijać się będą wsie nowoczesne, a najczęściej wsie tradycyjne $z$ formami (organizacjami) nowoczesnymi, gdyż tradycyjne nie oznacza zacofane, biedne i słabo zorganizowane, a jedynie mające większy szacunek do środowiska i przeszłości, w różnej formie i treści, szczególnie kulturowej (tradycje i obyczaje), społecznej, osadniczej, gospodarczej i przyrodniczo-krajobrazowej (kontynuacja brytyjskiej wizji „sielanki wiejskiej” - rural idyll - por. Bański 2009, s. 5).

\section{Perspektywy dalszego rozwoju geografii rolnictwa}

W najbliższych latach rozwój geografii rolnictwa w zakresie geografii obszarów wiejskich (geografii wsi) powinien koncentrować się, moim zdaniem, na trzech zasadniczych kwestiach:

1. dalszym doskonaleniu pola badawczego w sensie teoretycznym, metodycznym, jak i aplikacyjnym,

2. istotnym wkładzie wyników badań geograficzno-rolniczych do systemu nauk geograficznych i gospodarki przestrzennej w kraju i za granica,

3. ewolucji organizacyjnej w kierunku połączenia badań geograficzno-rolniczych i obszarów wiejskich, zwłaszcza w strukturze wyższych uczelni. 
Wynikiem uogólnień teoretycznych powinno być dążenie do zastąpienia niezwykle zróżnicowanych koncepcji teoretycznych (szczególnie $\mathrm{w}$ formie tradycyjnej) kilkoma najbardziej charakterystycznymi, takimi jak: orientacja strukturalistyczna, humanistyczna i postmodernistyczna. Specjalizacja w geografii społeczno-ekonomicznej poszerzyła stan wiedzy o wielu zjawiskach i procesach zachodzących w środowisku geograficznym i gospodarce, przyniosła bujny rozkwit wielu subdyscyplin tej dziedziny nauk geograficznych, ale jednocześnie przyczyniła się do jej dezintegracji, a zdaniem części geografów nawet do „zachwiana podstaw jej egzystencji" (Suliborski 2008, s. 85). Nowe paradygmaty (hipotezy i teorie) powinny wnieść nowe możliwości interpretacyjne, a tym samym poznawcze. W sensie metodologicznym powinny powstać nowe modele i wzorce metodyczne w zakresie: użytkowania ziemi, organizacji przestrzennej rolnictwa, rolnictwa podmiejskiego, rolnictwa ekologicznego, agroturystyki, rolniczych obszarów problemowych (konfliktowych), krajobrazów rolniczych, ochrony rolniczego środowiska przyrodniczego, typologii i regionalizacji rolnictwa oraz obszarów wiejskich. Aplikacyjność badań geograficzno-rolniczych powinna sprawić, aby uzyskane wyniki teoretyczno-metodyczne stały się istotnym wkładem w planach zagospodarowania przestrzennego i strategiach rozwoju lokalnego, regionalnego i ogólnokrajowego oraz stworzyły przesłanki dla wyraźnie określonego miejsca struktury przestrzennej rolnictwa polskiego w planach społeczno-gospodarczych UE, a zwłaszcza Europy Środkowo-Wschodniej (Bański 2001, 2013a, Falkowski 2001, 2004, Głębocki 2005, 2013).

Istotny wkład geografii rolnictwa do nauk geograficznych stanowią syntezy i opracowania monograficzne, np. regionalne, krajowe i w skali całego świata. Przykładem mogą być podręczniki akademickie (Kostrowicki 1973, Stola i Szczęsny 1976, 1982, Olszewski 1985, Falkowski, Kostrowicki 2001, Bański 2007), „Atlas rolniczy Polski” (Bański 2011), opracowania monograficzne, np. „Zróżnicowanie przestrzenne rolnictwa" pod red. B. Głębockiego (wyd. GUS, 2014), oraz mapy użytkowania ziemi i mapy krajobrazów rolniczych w skali 1:25000 $z$ lat 50 i 60. ub. wieku, wykonane w Zakładzie Geografii Rolnictwa IGiPZ PAN w Warszawie oraz kilku ośrodkach uniwersyteckich kraju, których opracowania zaniechano później, wobec trudności finansowych i organizacyjnych. W związku z potrzebami aplikacyjnymi (dla planów zagospodarowania przestrzennego oraz strategii rozwoju), a jednocześnie nowymi możliwościami technicznymi (m.in. zdjęciami satelitarnymi, teledetekcją, programami komputerowymi) warto, moim zdaniem, powrócić do opracowywania tych map.

Rolnictwo jako dział gospodarki zajmuje ponad $60 \%$ terytorium Polski (użytki rolne stanowią 51\%) i około $70 \%$ powierzchni obszarów wiejskich, daje zatrudnienie ponad połowie ludności wiejskiej oraz włącza w orbitę swojej współpracy (infrastruktura techniczna, usługi itp.) prawie całe spektrum zagadnień społecznych i ekonomicznych obszarów wiejskich. Dlatego uzasadnionym podejściem przez wiele lat była geografia rolnictwa jako odrębny dział geografii społeczno-ekonomicznej (podobnie jak w ujęciu branżowym tej części nauk geograficznych jak: geografia przemysłu, geografia komunikacji, geografia turyzmu, geografia religii itp. Gillmor (2004) uważa, że od drugiej połowy XX w. geografia rolnictwa 
stała się odrębną subdyscypliną geografii. Jako nauka geograficzno-ekonomiczna przez kilkadziesiąt lat wypracowała zarówno własne pole badawcze, metodykę, jak i określone efekty w postaci wspomnianych wyżej syntez oraz kierunków dalszych badań (Jasiulewicz 1998, Kulikowski 2004, Stasiak 2004, Czapiewski, Kulikowski 2005, Falkowski 2008). Kontynuowane są syntetyczne opracowania z geografii rolnictwa w literaturze zagranicznej (m.in.: Ilbery 1985, 1998, Pacione 1986, Bowler 1992, Sick 1997, Shafi 2000, Tarrant 2000, Grigg 2003, Majid 2004, Robinson 2004, Singh, Dhillon 2004, Singh 2004, Hanif 2005, Rumney 2005, Husain 2009, Ilieva 2012, Arbesman 2013, Laingen, Harrington 2013).

Od lat 60. ub. wieku ukazuje się coraz więcej opracowań z zakresu geografii rolnictwa i obszarów wiejskich. Są badania i konferencje naukowe oraz liczne opracowania łączące dwa filary geografii społeczno-ekonomicznej - wieś i rolnictwo (np. Choudhury, Singh 2000, Gillmor 2004; Mehta Press wydaje „Journal of Agricultural and Rural Geography" - Aims and Scope; konferencja w 2007 r. w Indianapolis - „Agricultural and Rural Geography”, w tym panel L.M.B. Harrington nt. „Zastosowanie geografii rolnictwa i obszarów wiejskich - 30 lat, spojrzenie wstecz"). W Unii Europejskiej działa Dyrekcja Generalna ds. Rolnictwa i Rozwoju Obszarów Wiejskich. Również w Polsce opracowuje się wiele dokumentów, zwłaszcza programów, planów, strategii i sprawozdań traktujących rolnictwo i obszary wiejskie łącznie, a jedno $z$ najważniejszych ministerstw RP to Ministerstwo Rolnictwa i Rozwoju Wsi.

W ostatnich latach w Polsce (co potwierdzają liczne publikacje) wzrosło w sposób zasadniczy zainteresowanie problematyką badawczą geografii obszarów wiejskich (por. Bański 2002, 2006, 2013 i Wójcik 2012 oraz ukazujące się od 1994 r. Studia Obszarów Wiejskich). Liczne przykłady opracowań monograficznych $z$ tego zakresu są też w literaturze zagranicznej (Clout 1972, Bonnamour 1973, Clark 1982, Pacione 1984, Gilg 1985, Halfacree 1997, Woods 2005 i in., publikacje zamieszczane m.in. w kwartalniku „Journal of Rural Studies”). Bański (2011) uważa, że współczesna geografia wsi jest w pełni wykształconą dyscypliną badawczą podejmującą problemy zróżnicowania przestrzeni wiejskiej oraz zachodzących w niej procesów i zjawisk społeczno-ekonomicznych. Obszary wiejskie są traktowane jako skomplikowany system powiązań elementów przyrodniczych, społecznych i ekonomicznych, jako miejsce pracy i życia człowieka (Bański 2012). Podobny pogląd wyraża Wójcik w monografii „Geografia wsi. Studium zmiany podstaw teoretyczno-metodologicznych" (2012). W polskich opracowaniach podkreśla się, że obszary wiejskie stanowią dziś niezwykle złożony organizm funkcjonalno-przestrzenny - są nie tylko obszarami sukcesu, ale też licznych niepowodzeń, trudności i barier rozwoju (Górz, Guzik 2003, Falkowski 2005a, Głębocki, Kaczmarek 2005, Głębocki, Kacprzak 2006).

$\mathrm{Na}$ obecnym etapie rozwoju nauk geograficznych w trosce o jedność formy i treści, a tym samym o zachowanie podmiotowości środowiska i człowieka oraz jego działalności gospodarczej wydaje się, że należy rozważyć pogląd o stopniowym odchodzeniu od ujęć specjalistycznych (branżowych - ekonomicznych, takich jak: rolnictwo, przemysł, turystyka itd.) w kierunku bardziej kompleksowych studiów miasta i wsi, w tym przypadku studiów z zakresu geografii 
obszarów wiejskich (geografii wsi). Pozwoli to (konkretnie w polskich warunkach, gdzie rolnictwo staje się jedną z funkcji w wielofunkcyjnym systemie obszarów wiejskich) na dokonanie nowych teoretyczno-metodycznych badań syntetyzujących dotychczasowy stan wiedzy oraz podjęcie nowych zagadnień, np.: społecznych, polityki organizacji i zarządzania obszarami wiejskimi, krajobrazu życia wiejskiego, przemian kulturowych wywołanych mas mediami oraz wpływu telekomunikacji (Internet, łączność komórkowa itp.).

Ważnym innowacyjnym otwarciem problematyki badawczej w dziedzinie geografii rolnictwa stało się zbiorowe opracowanie Zakładu Geografii Wsi i Rozwoju Lokalnego IGiPZ PAN w Warszawie, wykonane w 2012 r., a dotyczące diagnozy i oceny wykorzystania technologii informacyjno-komunikacyjnych jako elementu modernizacji i wielofunkcyjności rolnictwa, na przykładzie województwa mazowieckiego (Czapiewski i in. 2012). Opracowanie to, moim zdaniem, otwiera nowy rozdział $\mathrm{w}$ badaniach geograficzno-rolniczych (oraz obszarów wiejskich), nie tylko ze względu na podjętą innowacyjną problematykę, ale także na nowatorski wkład geografów do planów, projektów i programów rozwoju obszarów wiejskich oraz strategii ich rozwoju do 2030 r. w skali regionalnej, krajowej i w niedalekiej przyszłości także międzynarodowej. Potrzeby i możliwości włączenia wyników badań geograficznych w planowy rozwój przestrzeni wiejskiej wykazały m.in. referaty XXVIII Seminarium Geografii Wsi (Ełk 2012), opublikowane w t. 29 Studiów Obszarów Wiejskich. Poszczególne seminaria oraz Studia Obszarów Wiejskich sprzyjają wymianie myśli geograficznej i prezentacji wyników badań. Są ponadto wyrazem pewnej konsolidacji środowiska naukowego, przede wszystkim geografów, ale też przedstawicieli innych dyscyplin (oraz praktyki zarządzania i planowania) - zajmujących się szeroko rozumianą problematyką obszarów wiejskich.

Wyniki badań naukowych, uwzględniające rezultaty wybranych kompleksowych badań tradycyjnych oraz wpływu innowacji na wiele aspektów przyrodniczych, społecznych, ekonomicznych i kulturowych w strukturze przestrzennej rolnictwa (i szerzej obszarów wiejskich), dają szansę na szersze zainteresowanie tymi problemami nauki europejskiej i światowej. Tym samym polscy geografowie mogą wnieść większy wkład niż dotychczas w sferę zarówno osiągnięć teoretyczno-metodycznych, jak i aplikacyjnych tej dziedziny wiedzy, nie tylko w formie publikacji, ale także aktywniejszego udziału we wspólnych opracowaniach międzynarodowych, geograficznych oraz interdyscyplinarnych (np. w zakresie gospodarki przestrzennej, ochrony środowiska, studiów lokalnych i regionalnych). Umożliwi to poprawę kondycji badawczej nauk geograficznych, związanej m.in. $z$ potrzebą jednoczenia subdyscyplin nauk geograficznych, zwłaszcza w dziedzinie geografii społeczno-ekonomicznej, która w ostatnich latach, podobnie jak cała polska geografia, niewątpliwie przeżywa kryzys (Falkowski 2000, 2005, Liszewski i in. 2008, Bański 2010). 


\section{Literatura}

Arbesman S. 2013. The Geography of American Agriculture. US Department of Agriculture.

Bański J. 2001. Polskie rolnictwo na tle rolnictwa Unii Europejskiej - ocena dystansu. [W:] J. Bański (red.), Wieś i rolnictwo u progu Unii Europejskiej. Studia Obszarów Wiejskich, 1: 29-42.

Bański J. 2002. Geografia wsi - nowa dyscyplina badawcza polskiej geografii. Przegl. Geogr., 74, 3: $367-379$.

Bański J. (red.) 2004. Polska przestrzeń wiejska: procesy i perspektywy. Studia Obszarów Wiejskich, 6.

Bański J. 2005. Przestrzenny wymiar współczesnych procesów na wsi. Studia Obszarów Wiejskich, 9.

Bański J. 2006. Geografia polskiej wsi. PWE, Warszawa.

Bański J. 2007. Geografia rolnictwa Polski. PWE, Warszawa.

Bański J. 2009. Typy obszarów funkcjonalnych w Polsce. Ekspertyza dla MRR. IGiPZ PAN, Warszawa.

Bański J. 2010. Stan krytyczny polskiej geografii - krytyka stanu. Przegl. Geogr., 82, 4: 319-333.

Bański J. (red.) 2011. Atlas rolnictwa Polski. IGiPZ PAN, Warszawa.

Bański J. 2011. Wieś w badaniach geograficznych - ewolucja badań i przegląd koncepcji obszaru wiejskiego. [W:] M. Halamska (red.), Wieś jako przedmiot badań naukowych na początku XXI wieku. EUROREG, Wyd. Nauk. SCHOLAR, Warszawa: 29-44.

Bański J. 2013. O przyszłość polskiej wsi. [W:] J. Bański (red.), Polska wieś w perspektywie długookresowej - ujęcie regionalne. Studia Obszarów Wiejskich, 31: 9-24.

Bański J. (red.) 2013a. Polska wieś w perspektywie długookresowej - ujęcie regionalne. Studia Obszarów Wiejskich, 31.

Bąkowski A., Gorzelak G., Olechnicka A., Płoszaj A. 2007. Regionalne strategie innowacji w Polsce. Studia Regionalne i Lokalne, 1, 27: 88-111.

Błasiak W. 2005. Innowacyjność jako warunek rozwoju regionalnego i układów lokalnych. Formy i instrumenty innowacyjności w rozwoju regionalnym i lokalnym. Instytut Studiów i Projektów Rozwoju, Będzin.

Bonnamour J. 1973. Geographie rurale, methodes et perspectives. Masson, Paris.

Bowler I.R. (red.) 1992. The Geography of Agriculture in Developed Market Economies. Longman, Harlow.

Chojnicki Z. 2000. Filozofia nauki, orientacje, koncepcje, krytyki. Bogucki Wyd. Nauk., Poznań.

Choudhury R.C., Singh R.P. 2000. Rural Prosperity and Agriculture. Proceedings and Keynote Papers, New Delhi.

Churski P. 2008. Czynniki rozwoju regionalnego i polityka regionalna w Polsce w okresie integracji z Unią Europejską. Wyd. Uniwersytetu im. Adama Mickiewicza w Poznaniu.

Ciok S., Dobrowolska-Kaniewska H. 2009. Polityka innowacyjna a potencjał innowacyjny. Przykład Dolnego Śląska. Rozprawy Naukowe IGiRR, 7. Wrocław.

Clark G. 1982. Developments in rural geography. Area, 14: 249-254.

Clout H.D. 1972. Rural Geography. An Introductory Survey. Pergamon Press, Oxford.

Cymerman R., Falkowski J., Hopfer A. 1992. Krajobrazy wiejskie (klasyfikacja i kształtowanie). Wyd. AR-T, Olsztyn.

Czapiewski K., Kulikowski R. (red.) 2005. Dorobek naukowy geografii rolnictwa w Polsce. Studia Obszarów Wiejskich, 7.

Czapiewski K.Ł., Kulikowski R., Bański J., Bednarek-Szczepańska M., Mazur M., Ferenc M. 2012. Wykorzystanie ICT w rolnictwie Mazowsza - ujęcie przestrzenne. Studia Obszarów Wiejskich, 30.

European Commission Innovation in the national strategic reference frameworks. 2006. Working document of the Directorate General for Regional Policy, Brussels.

European Innovation Scoreboard. 2008. Brussels.

Falkowski J. 1993. Przekształcenia funkcjonalno-strukturalne i przestrzenne obszarów wiejskich Polski (ujęcie diagnostyczno-modelowe). Wyd. UMK, Toruń.

Falkowski J. 2000. Refleksje nad stanem obecnym i przyszłością geografii. [W:] B. Kortus, A. Jackowski, K. Krzemień (red.), Nauki geograficzne w poszukiwaniu prawdy o ziemi i człowieku. T. V. Wyd. IG UJ, Kraków, s. 169-176.

Falkowski J. 2001. Rolnictwo polskie w Unii Europejskiej (2005-2020) - scenariusz pesymistyczny - optymistyczny - realistyczny. [W:] J. Bański (red.), Wieś i rolnictwo u progu Unii Europejskiej. Studia Obszarów Wiejskich, 1: 53-70. 
Falkowski J. 2004. Miejsce obszarów wiejskich Polski w polityce regionalnej Unii Europejskiej. [W:] J. Parysek (red.), Rozwój regionalny i lokalny w Polsce w latach 1989-2003. Bogucki Wyd. Nauk., Poznań, s. 305-315.

Falkowski J. 2005. Geografia jako nauka o Ziemi, czyli o systemie relacji człowiek-środowisko-przestrzeń. [W:] J. Jania, A. Jankowski (red.), Wpływ rozwoju nauk geograficznych... Wyd. UŚ, Sosnowiec, s. 65-70.

Falkowski J. 2005a. Sukcesy i niepowodzenia w rozwoju obszarów wiejskich w latach 1989-2004. [W:] B. Głębocki, U. Kaczmarek (red.), Obszary sukcesu na polskiej wsi. Studia Obszarów Wiejskich, 8: 21-39.

Falkowski J. 2008. Stan i perspektywy rozwoju geografii ekonomicznej w Polsce. Geografia rolnictwa. [W]: S. Liszewski, J. Łoboda, W. Maik (red.), Stan i perspektywy rozwoju geografii w Polsce. KNG PAN, Wyd. Uczelniane WSG, Bydgoszcz, s. 143-149.

Falkowski J. 2009. Przekształcenia funkcjonalno-przestrzenne obszarów wiejskich w strefach podmiejskich obszarów metropolitalnych Polski. [W:] T. Komornicki, R. Kulikowski (red.), Miejsce obszarów wiejskich w zagospodarowaniu przestrzennym, Studia Obszarów Wiejskich, 18: 49-69.

Falkowski J., Kostrowicki J. 2001 (2005, wznowienie). Geografia rolnictwa świata. WN PWN, Warszawa.

Gilg A. 1985. An introduction to rural geography. Edward Arnold, Baltimore.

Gillmor D.A. 2004. Agricultural and rural geography. [W:] Encyclopaedia of Life Support Systems (EOLESS) UNESCO, Eoless, Oxford.

Głębocki B. (red.) 1998. Przestrzenna transformacja struktury agrarnej a wielofunkcyjny rozwój wsi w Polsce. Bogucki Wyd. Nauk., Poznań.

Głębocki B. (red.) 2005. Struktura przestrzenna rolnictwa Polski u progu XXI wieku. Bogucki Wyd. Nauk., Poznań.

Głębocki B. (red.) 2014. Zróżnicowanie przestrzenne rolnictwa. Wyd. GUS, Warszawa.

Głębocki B., Kaczmarek U. (red.) 2005. Obszary sukcesu na polskiej wsi. Studia Obszarów Wiejskich, 8.

Głębocki B., Kacprzak E. (red.) 2006. Przemiany struktury przestrzennej rolnictwa - sukcesy i niepowodzenia. Bogucki Wyd. Nauk., Poznań.

Górz B., Guzik C. 2003. Współczesne przeobrażenia i przyszłość wsi polskiej. Kraków.

Grigg D.B. 2003. The introduce of agricultural geography. Routledge.

Guzik R. 2004. Przestrzenne zróżnicowanie potencjału innowacyjnego w Polsce. [W:] M. Górzyński, R. Woodward (red.), Innowacyjność polskiej gospodarki. Zeszyty Innowacyjne, 2: 33-36.

Halfacree K.H. 1997. British rural geography: a perspective on the last decade. [W:] A.L. Ontiveros, F.M. Hernando, (red.) From traditional contryside to postproductivism: recent trends in rural geography in Britain and Spain. Asociacionde Geografos Espanoles, Murcia, s. 37-53.

Hanif M. 2005. Encyclopaedia of Agricultural Geography. Anmol Publications PVT.

Husain M. 2009. Systematic Agricultural Geography. Rawal Publication, Jaipur, New Delhi, s. 217 (reprint).

Ilbery B. 1985. Agricultural Geography: A Social and Economic Analysis. Oxford University Press, Oxford.

Ilbery B. (red.) 1998. The Geography of Rural Change. Addison, Wesley, Longman, Harlow.

Ilieva M. 2012. Socialno-ikonomiczeskaja transformacija w Bulgarija. Wyd. TepApt., Sofia.

Jasiulewicz M. 1998. Przekształcenia strukturalne i przestrzenne obszarów wiejskich i Pomorza Środkowego w okresie transformacji systemowej. Wyd. Uczelniane Politechniki Koszalińskiej, Koszalin.

Jezierska-Thole, Kozłowski L. (red.) 2008. Gospodarka przestrzenna w strefie kontinuum miejskowiejskiego w Polsce. Wyd. Naukowe UMK, Toruń.

Komornicki T., Kulikowski R. (red.) 2009. Miejsce obszarów wiejskich w zagospodarowaniu przestrzennym. Studia Obszarów Wiejskich, 18.

Kostrowicki J. 1973. Zarys geografii rolnictwa. PWN, Warszawa.

Kukliński A. 2005. Gospodarka oparta na wiedzy (GOW) jako nowy paradygmat trwałego rozwoju. Warszawa-Nowy Sącz.

Kukliński A., Pawłowska K. (red.) 1998. Innowacja - edukacja - rozwój regionalny. Wyd. Wyższa Szkoła Biznesu - National-Louis University, Nowy Sącz. 
Kulikowski R. 2004. Struktura przestrzenna rolnictwa Polski w świetle wyników PSR 2002. [W:] A. Stasiak (red.), Wieś polska w świetle wyników NSP 2002 r. i PSR 2002 r. Aspekty społeczne, ekonomiczne i przestrzenne. Biuletyn KPZK PAN, 213: 40-65.

Kurowska K., Gwiaździńska-Goraj M. (red.) 2012. Planowanie rozwoju przestrzeni wiejskiej. Studia Obszarów Wiejskich, 29.

Laingen C.R., Harrington L.M.B. 2013. Agricultural Geography. Oxford Bibliographies in Geography. Oxford University Press, Oxford.

Li L., Kozhikode R.K. 2009. Developing new innovation models: Shifts in the innovation landscapes in emerging economies and implications for global R\&D management. Journal of International Management, 15: 323-339.

Liszewski S., Łoboda J., Maik W. (red.) 2008. Stan i perspektywy rozwoju geografii w Polsce. KNG PAN, Wyd. Uczelniane WSG, Bydgoszcz.

Maik W. 2012. Podstawy teoretyczno-metodologiczne studiów geograficzno-miejskich. Wyd. Uczelniane WSG, Bydgoszcz.

Olszewski T. 1985. Geografia rolnictwa Polski. PWE, Warszawa.

Pacione M. 1984. Rural geography. Harper and Row, London.

Pacione M. 1986. Progress in Agricultural Geography. Croom Helm.

Parteka T., Kasprzak P. (red.) 2008. Innowacyjność - co to jest? Pomorskie Studia Regionalne, Gdańsk.

Pietrzyk I. 2004. Polityka regionalna Unii Europejskiej i regiony w państwach członkowskich. Wyd. Naukowe PWN, Warszawa.

Rainko S. 2011. Dwa paradygmaty. PIW, Warszawa.

Robinson G.M. 2004. Geographies of Agriculture. Globalization, Restructuring and Sustainability. Bussines \& Economic, Prentice Hall.

Rudnicki R. 2010. Zróżnicowanie przestrzenne wykorzystania funduszy Unii Europejskiej przez gospodarstwa rolne w Polsce w latach 2004-2006. Studia i Prace z Geografii i Geologii 17, Bogucki Wyd. Naukowe, Poznań.

Rudnicki R. (red.) 2010a. Fundusze Unii Europejskiej jako czynnik modernizacji rolnictwa polskiego. Bogucki Wyd. Naukowe, Poznań.

Rumney T.A. 2005. The study of agricultural geography. Scarecrow Press Inc., Lanham.

Rydz E. 1998. Restrukturyzacja i przekształcenia własnościowe w polskim rolnictwie (na przykładzie Pomorza Środkowego, Przegl. Regionalny, 2: 107-121.

Rydz E. 2006. Przemiany struktur społeczno-gospodarczych w okresie transformacji systemowej na Pomorzu Środkowym. Pomorska Akademia Pedagogiczna, Słupsk.

Rydz E., Rudnicki R. (red.) 2009. Procesy przekształceń przestrzeni wiejskiej. Studia Obszarów Wiejskich, 17.

Schumpeter J.A. 1960. Teoria rozwoju gospodarczego. PWN, Warszawa.

Shafi M. 2000. Agricultural Geography of South Asia. McMillan, Delhi.

Sick W.D. 1997. Agrargeographie. Westermann, Braunschweig.

Singh J., Dhillon S.S. 2004. Agricultural Geography. Tata McGraw Hill Publishing Co. Ltd., New Delhi.

Singh K.N. 2004. Agricultural Geography in India. New Delhi.

Stasiak A. (red.) 2004. Wieś polska w świetle wyników NSP 2002 r. i PSR 2002 r. (aspekty społeczne, ekonomiczne i przestrzenne). Biuletyn KPZK PAN, 213, Warszawa.

Stola W. 1987. Klasyfikacja funkcjonalna obszarów wiejskich Polski. Próba metodyczna. Prace habilitacyjne IGiPZ PAN, Warszawa.

Stola W., Szczęsny R. 1976 (1982 II wyd.). Geografia rolnictwa Polski. WSiP, Warszawa.

Suliborski A. 2008. O znaczeniu syntezy naukowej w geografii. [W:] S. Liszewski, J. Łoboda, W. Maik (red.), Stan i perspektywy rozwoju geografii w Polsce. Wyd. WSG, Bydgoszcz, s. 79-90.

Szulc H. 1995. Morfogeneza osiedli wiejskich w Polsce. Prace Geogr., 163, IGiPZ PAN. Continuo, Warszawa.

Szymoniuk B. 2005. Podwyższanie konkurencyjności regionu rolniczego: klaster „Dolina Ekologicznej Żywności". [W:] Z. Olesiński, A. Predygier (red.), Kreowanie konkurencyjności regionu. Grona przemysłowe w regionie. Wyd. Akademii Świętokrzyskiej, Kielce, s. 25-33.

Świadek A. 2008. Determinanty aktywności innowacyjnej w regionalnych systemach przemysłowych w Polsce. Rozprawy i Studia, 15/385. Uniwersytet Szczeciński, Szczecin. 
Tamowicz P., Szultka S. 2005. Innowacyjna gospodarka - na przekór stereotypom. Niebieskie Księgi PFSL, IBnGR, Gdańsk.

Taylor Z. 2008. Stan i perspektywy rozwoju geografii ekonomicznej w Polsce. Geografia komunikacji. [W:] S. Liszewski, J. Łoboda, W. Maik (red.), Stan i perspektywy rozwoju geografii w Polsce. Wyd. Uczelniane WSG, Bydgoszcz, s. 156-165.

Tarrant J.R. 2000. Agricultural Geography. A Halsted Press Book.

Wojnicka E. 2002. Rola klastrów innowacyjnych w Unii Europejskiej. Wspólnoty Europejskie, 5.

Wojnicka E., Rot P., Tamowicz P., Brodzki T. 2001. Regionalny system innowacyjny w województwie pomorskim. IBNGR, Polska Regionów, 26. Gdańsk.

Wolak-Sikorska I. 1993. Dyfuzja innowacji rolniczych w wiejskiej społeczności lokalnej i jej społecznoekonomiczne uwarunkowania. Rozprawy Naukowe i Monografie SGGW, 168. Warszawa.

Woods M. 2005. Rural Geography. Processes, Responses and Experiences in Rural Restructuring. SAGE Publications, London.

Wójcicki Z. 2000. Problemy modernizacji gospodarstw rolniczych. Problemy Inż. Roln., 3: 25-27.

Wójcik G. 2011. Znaczenie i uwarunkowania innowacyjności obszarów wiejskich w Polsce. Wiadomości Zootechniczne, XLIX, 1: 161-168.

Wójcik M. 2012. Geografia wsi. Studium zmiany podstaw teoretyczno-metodologicznych. Wyd. UŁ, Łódź.

Wójcik M. 2013. Geografia wsi w Polsce. Ewolucja koncepcji i problemów badawczych. [W:] M. Wójcik (red.), Koncepcje i problemy badawcze w geografii wsi. Acta Univ. Lodziensis, Folia Geographica Socio-Oeconomica, 13: 3-17.

Wspólnoty Europejskie. 2009. Przegląd Obszarów Wiejskich UE 2, Luxemburg, s. 32 i 53.

\title{
Traditional and innovation lines of polish agricultural geography studies. Agricultural geography and rural geography - together or divided?
}

\begin{abstract}
The aim of this article is to identify the current state of research in the field of agriculture geography, i.e. to make a distinction between 5 major periods of research (from the 30's of the last century up to 2013) in 12 geographical Polish scientific centers. Among the traditional 15 lines of research were distinguished: land use, typology and regionalization of agriculture, organization and spatial structure of agriculture, suburban agriculture, agricultural problem areas, organic farming, agriculture in spatial planning, Poland's and world agriculture. In the article were also distinguished 13 innovative directions in the geography of agriculture and rural areas, such as new methods and techniques of scientific research, multisensory landscape architecture, opportunities of eco-power industry, forms and methods to improve the quality of life and growth of human and social capital, the use of ICT (information and communication techniques), alternative sources of household income, geography of innovation clusters, a new organization of geographical research. Since the beginning of the 60 s of the last century a division in the research in the socio-economic geography of Poland has become noticeable: 1 - geographical and agricultural , 2 - geographical and agricultural and rural areas, 3 - rural areas geography (rural geography). At the same time for the benefit of the integration of geographical sciences, especially of economic geography, adopt a combination agricultural geography and rural areas in one sub-discipline - geography of rural areas (rural geography) ist peculiar.
\end{abstract}

Key words: centres of agricultural geography, traditional and innovative direction, rural geography 